\title{
The precarious persistence of the Endangered Sierra Madre yellow-legged frog Rana muscosa in southern California, USA
}

\author{
Adam R. Backlin, Cynthia J. Hitchcock, Elizabeth A. Gallegos \\ Julie L. Yee and Robert N. Fisher
}

\begin{abstract}
We conducted surveys for the Endangered Sierra Madre yellow-legged frog Rana muscosa throughout southern California to evaluate the current distribution and status of the species. Surveys were conducted during 2000-2009 at 150 unique streams and lakes within the San Gabriel, San Bernardino, San Jacinto, and Palomar mountains of southern California. Only nine small, geographically isolated populations were detected across the four mountain ranges, and all tested positive for the amphibian chytrid fungus Batrachochytrium dendrobatidis. Our data show that when $R$. muscosa is known to be present it is easily detectable $(89 \%)$ in a single visit during the frog's active season. We estimate that only 166 adult frogs remained in the wild in 2009. Our research indicates that $R$. muscosa populations in southern California are threatened by natural and stochastic events and may become extirpated in the near future unless there is some intervention to save them.
\end{abstract}

Keywords Abundance estimates, amphibian decline, California, conservation, detection probability, Rana muscosa, Sierra Madre yellow-legged frog

\section{Introduction}

$\mathrm{T}$ he Sierra Madre yellow-legged frog Rana muscosa, formerly known as the mountain yellow-legged frog, is endemic to California. Historically, it occurred in the Sierra Nevada at an elevation of 1,370-3,660 $\mathrm{m}$ and in the San Gabriel, San Bernardino, San Jacinto and Palomar mountains of California at 370-2,290 m (Stebbins, 2003). The species was once common in these mountain ranges (Schoenherr, 1976; Jennings \& Hayes, 1994; Stebbins \& Cohen, 1997) but populations have been declining throughout the state since the late 196os (Bradford et al., 1994; Jennings \& Hayes, 1994; Stebbins \& Cohen, 1997; Knapp \& Matthews, 2000; Vredenburg et al., 2007). Taxonomic

AdAm R. BACKLin (Corresponding author), Cynthia J. HitchCock, Elizabeth A. Gallegos and Robert N. Fisher San Diego Field Station, U.S. Geological Survey, Western Ecological Research Center, 4165 Spruance Road, Suite 200, San Diego, California, USA. E-mail abacklin@usgs.gov

JuLIe L. Yee U.S. Geological Survey, Western Ecological Research Center, Sacramento, California, USA

Received 10 September 2012. Revision requested 18 October 2012.

Accepted 20 February 2013. First published online 21 November 2013. revisions by Macey et al. (2001) demonstrated that this species comprises four evolutionarily distinct subgroups within two major clades. The southernmost subgroup of R. muscosa (occurring in southern California) was identified as a distinct population segment and was categorized as Endangered by the U.S. Fish and Wildlife Service on 1 August 2002 (U.S. Fish and Wildlife Service, 2002). Further taxonomic revisions (Vredenburg et al., 2007) divided $R$. muscosa into two distinct species, R. muscosa in the south and $R$. sierrae in the north, with the geographical transition zone occurring in the southern Sierra Nevada. To help guide restoration efforts, Schoville et al. (2011) evaluated R. muscosa by means of microsatellite and mitochondrial analysis and found a high degree of historical isolation across the remaining mountain ranges. This study only covers R. muscosa populations located within the San Gabriel, San Bernardino, San Jacinto, and Palomar mountains of southern California (Fig. 1), hereafter referred to as the southern California populations; it does not address R. muscosa populations in the Sierra Nevada. Currently the southern California populations of R. muscosa are categorized as Endangered by the IUCN (IUCN, 2013), the U.S. Fish and Wildlife Service, and the State of California, where the Fish and Game Commission listed R. muscosa as Endangered under the California Endangered Species Act, effective 1 April 2013 (Title 14, California Code of Regulations, Section 670.5).

\section{Methods}

\section{Historical occurrence}

We compiled 694 historical records of R. muscosa from southern California from museums, reports, publications and field notes. Museums included AMNH, ANSP, CAS and CAS-SU, CM, CMC, CU, FMNH, KU, LACM, LSU, MVZ, PSM, RMMU, SDNHM, TCWC, UAZ, UMMZ, and USNM (acronyms follow Leviton et al., 1985). These records were used to guide the selection and prioritization of survey locations and evaluate potential historical declines. To illustrate the extent of reported declines we created a histogram showing the number of museum records by decade from 1900 to the present. Of the 670 museum records collected, 659 had dates associated with the records and were included in the histogram. We then evaluated the locality description 


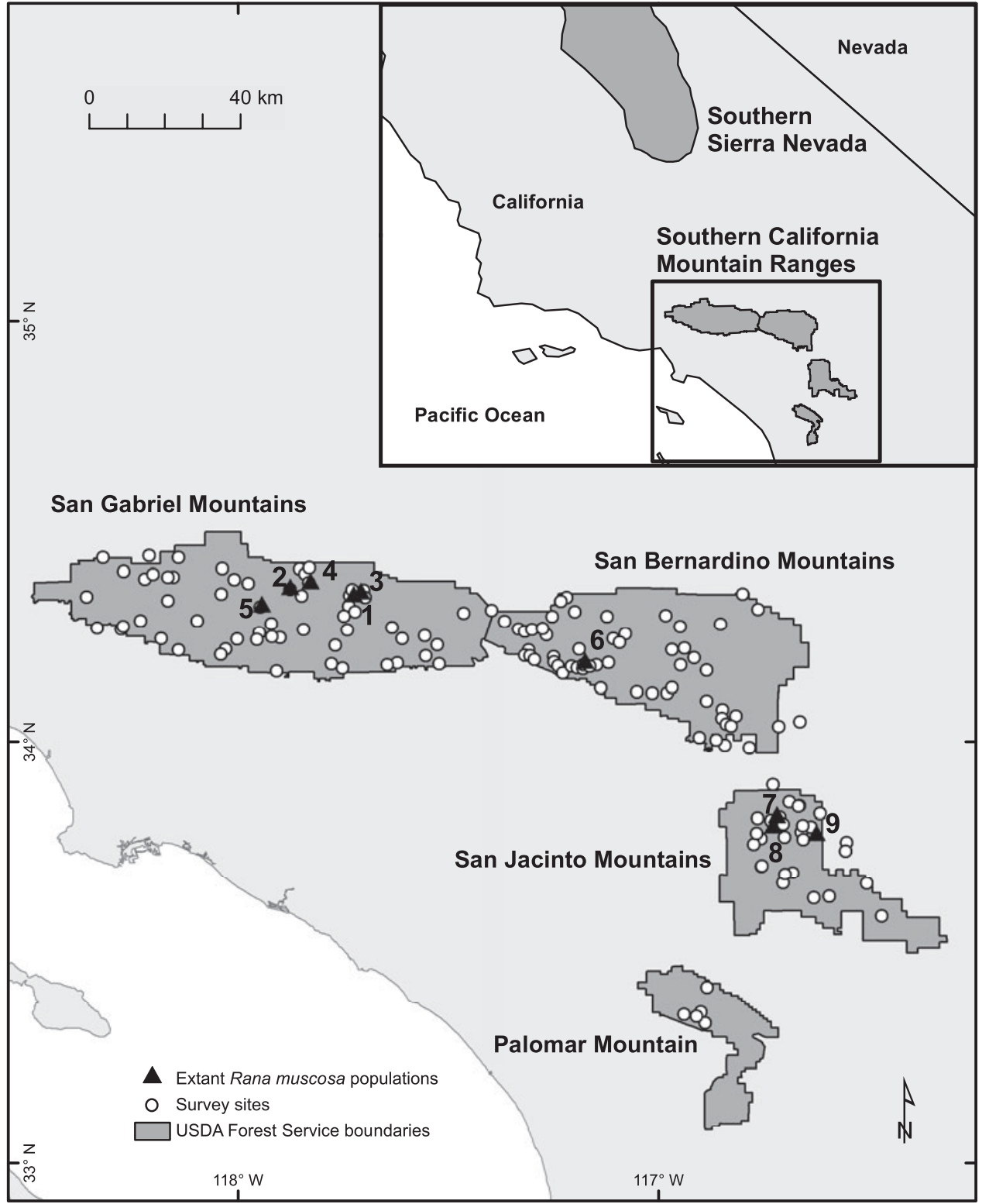

FIG. 1 Location of survey sites and extant populations of the Sierra Madre yellow-legged frog Rana muscosa in southern California. The extant populations are located at (1) Bear Gulch, (2) Little Rock Creek, (3) Vincent Gulch, (4) Big Rock Creek, (5) Devils Canyon, (6) City Creek, (7) Fuller Mill Creek, (8) Dark Canyon, and (9) Tahquitz Creek. The inset shows the location of the main map in California. for each record and identified the unique number of sites where collections were made each decade (Fig. 2).

\section{Field inventories}

We surveyed a total of 150 unique streams and lakes. Surveys included visiting sites with historical records, monitoring known populations of $R$. muscosa and assessing neighbouring sites with potential suitable habitat. Daytime visual encounter surveys were conducted during $R$. muscosa peak activity season (from the end of April to October; Zweifel, 1955), with two individuals walking slowly in or near the stream channel to detect all age classes and record and process individuals found. Multiple visits were made to sites with extant frog populations to determine the detection

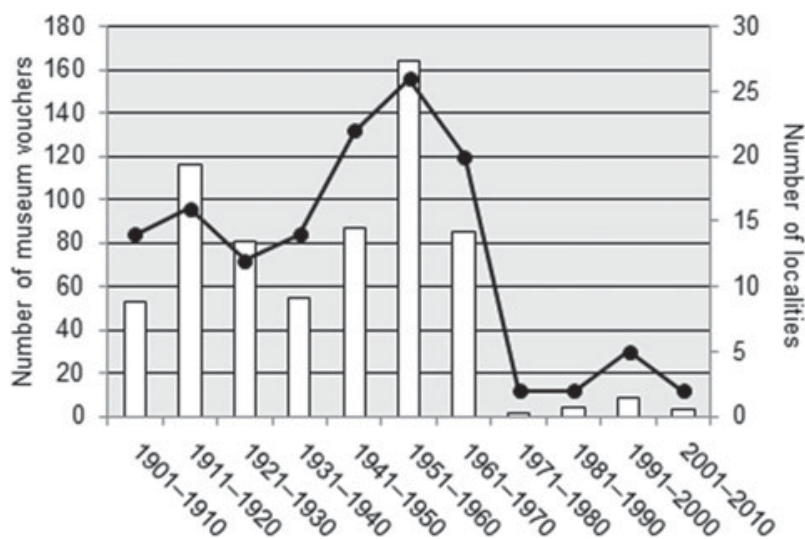

FIG. 2 Numbers of R. muscosa vouchers deposited in museums since 1900. Bars represent the number of museum vouchers collected per decade and the line represents the number of unique localities where the vouchers were collected. 
TABLE 1 Cumulative probability of detecting the Sierra Madre yellow-legged frog Rana muscosa with repeat surveys, from our survey of southern California (Fig. 1) during 2001-2009, with survey number, probability estimate, and lower and upper $95 \%$ confidence limits.

\begin{tabular}{ll}
\hline Survey & Probability estimate $(95 \%$ confidence interval) \\
\hline 1 & $0.886(0.797-0.896)$ \\
2 & $0.987(0.959-0.989)$ \\
3 & $0.999(0.992-0.999)$ \\
4 & $1.000(0.998-1.000)$ \\
5 & $1.000(1.000-1.000)$ \\
6 & $1.000(1.000-1.000)$ \\
7 & $1.000(1.000-1.000)$ \\
8 & $1.000(1.000-1.000)$ \\
\hline
\end{tabular}

probability of this species and to estimate population sizes. A minimum of one visit was made to all other survey sites to determine habitat suitability and $R$. muscosa occupancy.

\section{Population analysis}

The detectability of R. muscosa, using our survey protocol, was determined post hoc. We used data from repeated surveys at all sites with extant populations from 2001 to 2009. We analysed the probability of detecting $R$. muscosa on multiple surveys using log-linear modelling, with PRESENCE (MacKenzie et al., 2002).

Population sizes at occupied sites were estimated using mark-recapture methods. Frogs were marked with passive integrated transponder tags. Estimated population sizes pertain only to adult $R$. muscosa. Juveniles were difficult to quantify because our federal recovery permit TE-045994 allowed us to tag only those individuals $>50 \mathrm{~mm}$ snout to vent length. Tadpoles and eggs were also difficult to quantify because they are challenging to detect and mark.

We estimated the population size at each of seven locations with extant populations for most years from 2001 to 2009, for a total of 54 populations. We used the Huggins closed capture model in MARK to estimate detection rates and derive abundance at each site for years when surveys occurred (Lukacs, 2012). Unlike the Cormack-Jolly-Seber open population model, which requires capture rates to equal recapture rates, the Huggins model estimates these rates separately by assuming negligible loss or recruitment during each capture season (11 May-24 September). Although the robust Cormack-Jolly-Seber open population model also assumes population closure between closely spaced intervals from the same period (i.e. year) and can estimate capture and recapture separately, we chose the Huggins model to estimate population patterns empirically rather than by further modelling of open population dynamics. An eighth location, Vincent Gulch, was sampled from 2001 to 2009 but was excluded from modelling because it had $<18$ total captures and no same-year recaptures. A ninth location, Tahquitz Creek, was also excluded from the model because it was rediscovered in 2009 and is known for only five adult female frogs. We divided the season into seven time intervals representing up to seven captures. A population was sampled for a mean of $3.1 \pm 1.4$ time intervals in a year. For certain combinations of site, year, and time interval when a population was not sampled, we constrained the capture and recapture rates to equal 0 .

We evaluated 144 models in which the capture or recapture rates varied across years, time intervals or sites and compared these with models where the rates were constant. We included in our comparisons models based on specific hypotheses that capture or recapture rates follow a linear trend with time or year, or have a quadratic relationship with time as a result of peaks of activity in the summer. We used $R$ and RMark as an interface for processing all models in MARK (White \& Burnham, 1999; R Development Core Team, 2012; Laake \& Rexstad, 2012; Laake et al., 2012). We estimated overdispersion to be $\hat{c}=1.1$ by using the median $\hat{c}$ approach in MARK, and compared all models and calculated model weights using the quasi-Akaike information criterion (QAICc). We identified a subset of models with the strongest support (QAICc weight $>1 \%$ ) and performed model-averaging to compute estimates, standard errors and $95 \%$ confidence limits of population size.

\section{Disease screening}

All frogs captured were visually assessed for signs of disease and parasites. They were immediately swabbed to test for the amphibian chytrid fungus, following the protocol outlined in Hyatt et al. (2007). Swabs were processed at the University of California, Berkeley, and the San Diego Zoo Institute for Conservation Research.

\section{Results}

\section{Historical occurrence}

R. muscosa from southern California were recorded in literature, field notes and museum databases from 1903 to 2002, with a sharp decline in the number of records after the 1960s. In addition to this decline there was a reduction in the number of sites where vouchers were collected (Fig. 2). Since 1971 there has not been a decade when $R$. muscosa was collected from more than five sites. This is consistent with their current distribution.

\section{Field inventories}

Between 2000 and 2009150 unique streams and lakes were surveyed for R. muscosa in southern California. R. muscosa 
TABle 2 Top 20 models of capture and recapture rates of $R$. muscosa in seven extant populations during the active season (May-September) for 2000-2009. All models were Huggins closed capture models, and capture (p) and recapture (c) rates were based on combinations of seasonal (Time) and/or yearly (Year) trends and site variation (site). Models are adjusted for overdispersion and evaluated based on quasi-Akaike information criteria (QAICc). Models are ordered from best to worst according to QAICc, difference in QAICc relative to the best model ( $\triangle \mathrm{QAICc}$ ), weight of evidence supporting each model (QAICc weight), number of parameters, and quasi-deviance. Similar models based on categorical effects of season and year (Time, Year) had less than $<0.01$ weight of support.

\begin{tabular}{|c|c|c|c|c|c|}
\hline Model & QAICc & $\triangle \mathrm{QAICc}$ & $\begin{array}{l}\text { QAICc } \\
\text { weight }\end{array}$ & $\begin{array}{l}\text { No. of } \\
\text { parameters }\end{array}$ & $\begin{array}{l}\text { Quasi- } \\
\text { deviance }\end{array}$ \\
\hline $\begin{array}{l}\left\{\mathrm{p}\left(\sim 1+\text { Time }+\mathrm{I}\left(\text { Time }^{\wedge} 2\right)+\text { Year }\right) \mathrm{c}(\sim 1+\text { Time }+\right. \\
\left.\left.\mathrm{I}\left(\text { Time }^{\wedge} 2\right)+\text { Year }+ \text { site }\right)\right\}\end{array}$ & $1,731.32$ & 0.00 & 0.16 & 14 & $2,075.40$ \\
\hline$\left\{\mathrm{p}(\sim 1+\right.$ Time $) \mathrm{c}\left(\sim 1+\right.$ Time $+\mathrm{I}\left(\right.$ Time $\left.^{\wedge} 2\right)+$ site $\left.)\right\}$ & $1,732.48$ & 1.16 & 0.09 & 11 & $2,082.60$ \\
\hline$\left\{\mathrm{p}(\sim 1+\right.$ Year $) \mathrm{c}\left(\sim 1+\right.$ Time $+\mathrm{I}\left(\right.$ Time $\left.^{\wedge} 2\right)+$ site $\left.)\right\}$ & $1,732.69$ & 1.36 & 0.08 & 11 & $2,082.81$ \\
\hline$\left\{\mathrm{p}(\sim 1+\right.$ Time $) \mathrm{c}\left(\sim 1+\right.$ Time $+\mathrm{I}\left(\right.$ Time $\left.^{\wedge} 2\right)+$ Year + site $\left.)\right\}$ & $1,732.71$ & 1.38 & 0.08 & 12 & $2,080.82$ \\
\hline$\{\mathrm{p}(\sim 1+$ Time $) \mathrm{c}(\sim$ site $)\}$ & $1,732.90$ & 1.57 & 0.08 & 9 & $2,087.04$ \\
\hline$\left\{\mathrm{p}(\sim 1+\right.$ Year $) \mathrm{c}\left(\sim 1+\right.$ Time $+\mathrm{I}\left(\right.$ Time $\left.^{\wedge} 2\right)+$ Year + site $\left.)\right\}$ & $1,732.92$ & 1.60 & 0.07 & 12 & $2,081.03$ \\
\hline$\{\mathrm{p}(\sim 1+$ Year $) \mathrm{c}(\sim 1+$ Year $)\}$ & $1,733.00$ & 1.68 & 0.07 & 2 & $2,101.19$ \\
\hline$\{\mathrm{p}(\sim 1+$ Year $) \mathrm{c}(\sim$ site $)\}$ & $1,733.09$ & 1.77 & 0.07 & 9 & $2,087.23$ \\
\hline$\left\{\mathrm{p}\left(\sim 1+\right.\right.$ Time $+\mathrm{I}\left(\right.$ Time $\left.\left.^{\wedge} 2\right)\right) \mathrm{c}\left(\sim 1+\right.$ Time $+\mathrm{I}\left(\right.$ Time $\left.^{\wedge} 2\right)+$ site $\left.)\right\}$ & $1,733.98$ & 2.66 & 0.04 & 12 & $2,082.09$ \\
\hline$\left\{\mathrm{p}\left(\sim 1+\right.\right.$ Time $+\mathrm{I}\left(\right.$ Time $\left.\left.^{\wedge} 2\right)\right) \mathrm{c}\left(\sim 1+\right.$ Time $+\mathrm{I}\left(\right.$ Time $\left.^{\wedge} 2\right)+$ Year + site $\left.)\right\}$ & $1,734.21$ & 2.89 & 0.04 & 13 & $2,080.30$ \\
\hline$\left\{\mathrm{p}\left(\sim 1+\right.\right.$ Time $+\mathrm{I}\left(\right.$ Time $\left.\left.^{\wedge} 2\right)\right) \mathrm{c}(\sim$ site $\left.)\right\}$ & $1,734.40$ & 3.07 & 0.04 & 10 & $2,086.53$ \\
\hline$\left\{\mathrm{p}(\sim\right.$ site $) \mathrm{c}\left(\sim 1+\right.$ Time $+\mathrm{I}\left(\right.$ Time $\left.^{\wedge} 2\right)+$ Year + site $\left.)\right\}$ & $1,734.69$ & 3.36 & 0.03 & 16 & $2,074.73$ \\
\hline$\{\mathrm{p}(\sim 1+$ Time $) \mathrm{c}(\sim 1+$ Year $)\}$ & $1,734.83$ & 3.51 & 0.03 & 3 & $2,101.02$ \\
\hline$\left\{\mathrm{p}(\sim 1+\right.$ Time $) \mathrm{c}\left(\sim 1+\right.$ Time $+\mathrm{I}\left(\right.$ Time $\left.^{\wedge} 2\right)+$ Year + site $\left.)\right\}$ & $1,735.33$ & 4.01 & 0.02 & 19 & $2,069.32$ \\
\hline$\left\{\mathrm{p}(\sim 1+\right.$ Year $) \mathrm{c}\left(\sim 1+\right.$ Time $+\mathrm{I}\left(\right.$ Time $\left.^{\wedge} 2\right)+$ Year + site $\left.)\right\}$ & $1,735.54$ & 4.22 & 0.02 & 19 & $2,069.53$ \\
\hline$\left\{\mathrm{p}\left(\sim 1+\right.\right.$ Time $+\mathrm{I}\left(\right.$ Time $\left.^{\wedge} 2\right)+$ Year $) \mathrm{c}\left(\sim 1+\right.$ Time $+\mathrm{I}\left(\right.$ Time $\left.^{\wedge} 2\right)+$ site $\left.)\right\}$ & $1,736.00$ & 4.68 & 0.02 & 13 & $2,082.10$ \\
\hline$\{\mathrm{p}(\sim 1+$ Time $) \mathrm{c}(\sim 1+$ Time $)\}$ & $1,736.03$ & 4.71 & 0.02 & 4 & $2,100.21$ \\
\hline$\{\mathrm{p}(\sim 1+$ Year $) \mathrm{c}(\sim 1+$ Time $)\}$ & $1,736.23$ & 4.9 & 0.01 & 4 & $2,100.41$ \\
\hline$\left\{\mathrm{p}\left(\sim 1+\right.\right.$ Time $+\mathrm{I}\left(\right.$ Time $\left.\left.^{\wedge} 2\right)\right) \mathrm{c}(\sim 1+$ Year $\left.)\right\}$ & $1,736.33$ & 5.00 & 0.01 & 4 & $2,100.51$ \\
\hline$\left\{\mathrm{p}\left(\sim 1+\right.\right.$ Time $+\mathrm{I}\left(\right.$ Time $\left.^{\wedge} 2\right)+$ Year $) \mathrm{c}(\sim$ site $\left.)\right\}$ & $1,736.41$ & 5.09 & 0.01 & 11 & $2,086.53$ \\
\hline
\end{tabular}

was only detected at nine of these sites (Fig. 1). There were known to be extant populations at seven of the sites prior to the study: Bear Gulch, Devils Canyon, Little Rock Creek, Vincent Gulch, City Creek, Dark Canyon and Fuller Mill Creek. Only two populations were rediscovered at the remaining 143 sites: a population at Big Rock Creek in 2000 and a population at Tahquitz Creek in 2009. The previous records from Big Rock Creek and Tahquitz Creek were from 1959 and 1972, respectively. Also during this study two extant populations became undetectable for a short duration (Bear Gulch and City Creek) but were later rediscovered in low numbers. We did not detect $R$. muscosa at three sites where it was known to occur in the 1990s: Hall Canyon (three surveys over 3 years), the North Fork San Jacinto River, below California State Route 243 (10 surveys over 3 years), and the East Fork San Gabriel River (six surveys over 2 years; M.R. Jennings, pers. comm.) despite multiple visits over multiple years.

\section{Population analysis}

Our detection probability for R. muscosa for a single survey was $89 \pm$ SE $0.025 \%$ (95\% CI $0.797-0.896)$ for all sites with known populations of this species, using data from 9 years.
This detectability estimate is high for $R$. muscosa in southern California. Detectability estimates were also calculated for repeat surveys $(\mathrm{n}=1-8)$ within a single year (Table 1), with detectability reaching $99 \%$ after two surveys and $100 \%$ after three or more surveys at any site within a single year.

The best supported closed population capture models include a quadratic time effect, site, and sometimes a yearly trend (Table 2). Site was a strong influencing factor on recapture rates but not on initial captures. Devils Canyon and Little Rock Creek had the highest recapture rates, and Fuller Mill Creek had the lowest. The quadratic time effects had negative coefficients, suggesting peaks in the relationship with time. The coefficient of the yearly trends tended to be positive, suggesting that capture and recapture efficiency may have improved in later years. For several of the top models we evaluated the support for simpler models in which capture and recapture rates had identical trends. However, these models had lower QAICc weights than their counterparts when capture and recapture rates were separate.

Our abundance estimates for 2009 total only 166 adults across seven locations (Table 3). Furthermore, during 9 years of repeated surveys we have only been able to mark 314 unique individuals across all sites. Individuals have 


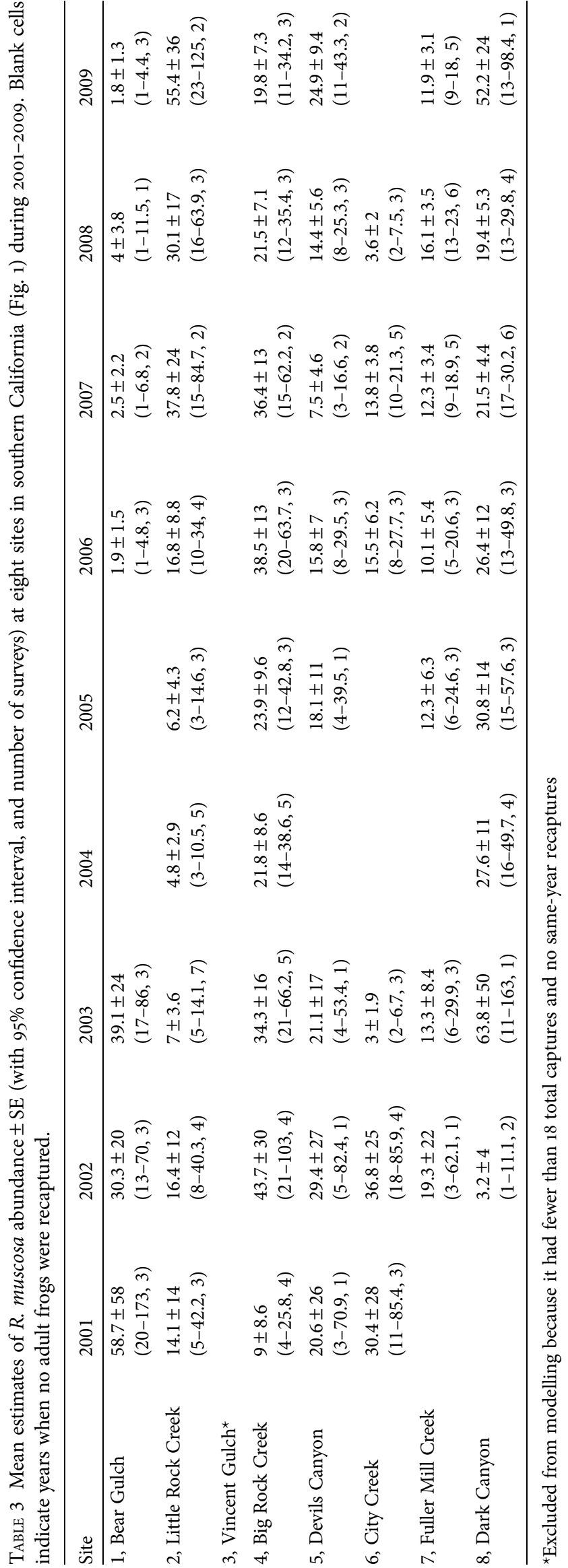

been captured up to 12 times during this period. Over the 9 years we have observed populations increasing (Little Rock Creek, Dark Canyon), decreasing (Bear Gulch, City Creek) and remaining stable (Big Rock Creek, Devils Canyon, Fuller Mill Creek; Table 3; Fig. 3).

\section{Disease screening}

A total of 707 R. muscosa adults, juveniles and tadpoles were swabbed and processed between 2001 and 2009. Forty-four individuals tested positive for the amphibian chytrid fungus (6\% prevalence) and all of these were infected with low-level loads. All extant $R$. muscosa populations in southern California have individuals that tested positive for the fungus. The number of infected individuals recorded per site ranged from one at Bear Gulch to 24 at City Creek.

\section{Discussion}

Vredenburg et al. (2007) reported a 98.1\% decline of R. muscosa in southern California. Historically these frogs occupied five mountain ranges, four in southern California and the Sierra Nevada. Within our study area they are presumed extinct from Palomar Mountain, and City Creek is the only known population remaining in the San Bernardino Mountains. The City Creek population has declined and is at risk of extirpation in the near future because of the low number of individuals. The other eight populations occur in the San Gabriel $(\mathrm{n}=5)$ and San Jacinto $(\mathrm{n}=3)$ mountains. All remaining populations are small ( $\leqslant 55$ adults) and geographically isolated from one another. Based on mitochondrial and microsatellite datasets, every population appears to be genetically isolated, with very little inter-population gene flow (Schoville et al., 2011).

The detection probability of $R$. muscosa at the sites we modelled is high (89\%), indicating that this species can be highly visible where it occurs. The data used in this analysis were collected from every known population of $R$. muscosa in southern California, including the most difficult survey locations and the smallest populations (Table 3). This $89 \%$ detectability is the probability of detecting $R$. muscosa at occupied sites when they are active and does not reflect the probability of detecting $R$. muscosa at any random site. The detectability was calculated to help us refine our survey protocol and to provide a better understanding of the probability of detecting new populations at sites to be surveyed. The high detection probability of this species is consistent with historical observations before and during the 1960s (Wright \& Wright, 1949; Schoenherr, 1976; Jennings \& Hayes, 1994). R. muscosa are diurnal, basking on sunny rocks, and their tadpoles are present year-round in 

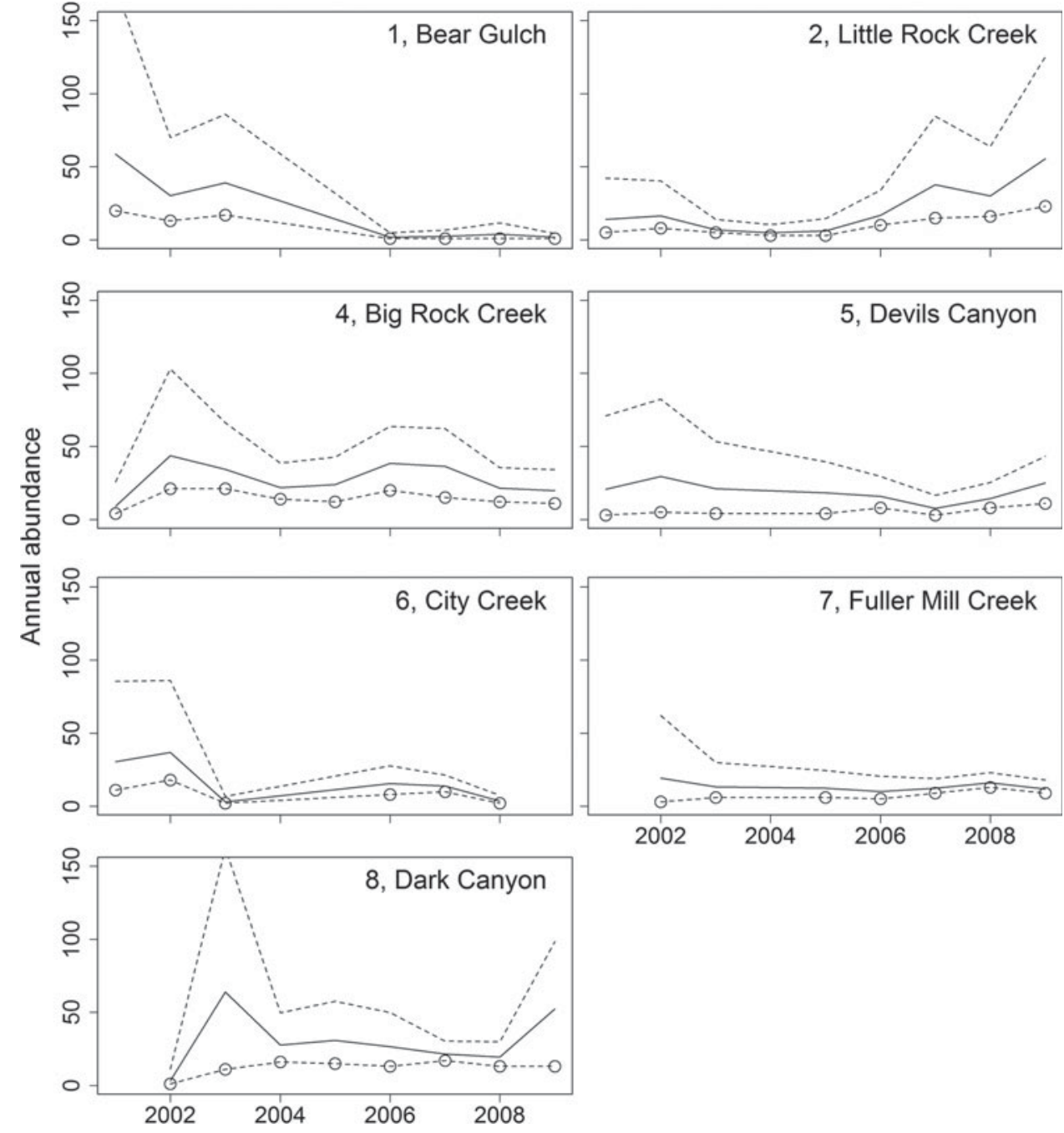

FIG. 3 Annual abundance estimates for $R$. muscosa adults (solid line) from 2001 to 2009 , with $95 \%$ confidence interval (dashed lines). Circles represent the number of unique frogs captured and are minimum estimates of the population size. There are no circles for years when no adult frogs were captured, and values are interpolated for those years. Vincent Gulch and Tahquitz Creek populations are not included because there were no same-year recaptures there.

streams, making them easy to detect (Zweifel, 1955; Jennings \& Hayes, 1994; Vredenburg et al., 2005, 2007).

Given the high detectability of this species it is notable that only nine small populations were detected across 150 unique locations surveyed throughout their historical distribution. Our current abundance estimates are small (1-55 adults per population; Table 3). Our data indicate that most of the remaining populations have fewer than 10 pairs of adults. Very small populations, consisting of $<10$ pairs, are considered to be highly vulnerable to stochastic events and are likely to become extinct in the short term (Pimm et al., 1988). We have seen evidence of vulnerability to stochastic events in two of the nine remaining populations, City Creek and Bear Gulch. At City Creek wildfires followed by heavy rains and debris flows in 2003 nearly extirpated the population. Frogs were detectable again in small numbers in 2005 but have not recovered to pre-wildfire numbers (Table 3; Fig. 3). Despite the reappearance of small numbers of frogs, this population remains at risk of extirpation. At Bear Gulch R. muscosa was undetectable in 2004 and continues to persist at low numbers, and the causes of decline are unclear. The City Creek and Bear Gulch populations were two of the largest in southern California between 2000 and 2003 but according to our data both are now nearly extirpated (Table 3).

Amphibian chytrid fungus has been detected across all nine populations of $R$. muscosa in southern California, but we have never detected a mass die-off such as those described at other locations (Berger et al., 1998; Muths et al., 2003; Lips et al., 2006; Vredenburg et al., 2010). In southern California $R$. muscosa appears to persist with low-level fungal infection. Briggs et al. (2010) found similarly low-level infection at sites where R. muscosa and Rana sierrae populations survived an initial invasion of the fungus in the Sierra Nevada. Based on the low-level infection intensities in all $R$. muscosa populations in southern California the fungus may have moved across southern California in a manner similar to that documented in the Sierra Nevada (Vredenburg et al., 2010), although we have found no documentation of this occurring.

If amphibian chytrid fungus spread across southern California in the late 1960s it could have reduced and 
fragmented $R$. muscosa populations. The decline in museum vouchers collected and the reduction in the number of sites of those collections potentially indicate a decreasing trend in the late 1960s. As an alternative we examined California Department of Fish and Wildlife fish stocking records across the historical distribution of $R$. muscosa for the San Gabriel, San Bernardino and the San Jacinto mountains. Stocking occurred from 1940 to 1999, with sites stocked between one and 52 times across this region. It is unlikely that fish stocking caused this abrupt decline in the late 1960 s as there were continuous stocking efforts from 1940 to 1999. We queried HerpNet (HerpNet, 2013) for all reptile and amphibian captures across five southern California counties to ascertain the field collection effort. We found a continuous collecting effort from 1908 to 1987 , with a peak collecting period between 1970 and 1972, suggesting that field collection effort is unlikely to be the cause of the reduced number of $R$. muscosa vouchers in museums. Future studies evaluating museum collections for amphibian chytrid fungus would indicate when the fungus began appearing in $R$. muscosa populations and how it spread geographically. Whatever the cause, since the initial dropoff the remaining populations continue to be affected by additional stressors (hydrologic fragmentation, non-native trout, wildfires, recreation) resulting in the current fragmented distribution and extremely small population sizes.

\section{Conclusions and management recommendations}

The causes of the decline of $R$. muscosa in the area we studied remain unknown but there are several possibilities, including the spread of amphibian chytrid fungus, loss of habitat as a result of human recreation and urbanization, and the introduction of predatory fish. Since this study began the remaining populations have persisted, with precariously low numbers of individuals. Several documented stochastic events have had further negative effects on some of the remaining populations.

To preserve current populations and ensure the persistence of $R$. muscosa in southern California we recommend: (1) protecting and expanding current populations, (2) increasing the number of populations by repatriating historical sites with suitable habitat, and (3) establishing neighbouring populations where suitable habitat exists, to promote natural recolonization and gene flow between populations.

We have several preliminary projects underway. To protect remaining populations from further decline we have been working closely with state, federal and local agencies at several sites to decrease recreational activity adjacent to frog populations, remove non-native predatory fish and create fish barriers to protect frog-occupied areas. We have also established a captive breeding programme at the San Diego
Zoo Institute for Conservation Research and the Los Angeles Zoo and Botanical Gardens, from which we now have individuals to repatriate historical areas, provided the stock animals are disease-free and there are suitable sites for repatriation. Genetic analyses of current populations are also being used to consider the best way to repatriate while conserving the natural genetic structure of the remaining populations.

Much work is still needed to determine how to reestablish this species to a point where it will be at less risk of extirpation. We intend to continue monitoring extant populations of $R$. muscosa in southern California for disease, predators and population trends. We will continue to study and apply new ways to increase the number of populations and of individuals within populations in the hope that one day they will become self-sustaining.

\section{Acknowledgements}

We are grateful to Jesse Bennett, Betsy Bolster, Randi Logsdon, Kathie Meyer and Susan North for their advice on recovering $R$. muscosa and their help in the field, and for providing permits. Thanks to Vance Vredenburg and Allen Pessier for their expert advice and for analysing swabs for amphibian chytrid fungus. We thank Kent Beaman for providing historical information not found in the literature or museum records, and Cheryl Brehme for assistance with statistical analysis. Funding was provided by the U.S. Fish and Wildlife Service, California Department of Fish and Wildlife, California Department of Transportation, and USDA Forest Service. This is contribution 421 of the U.S. Geological Survey Amphibian Research and Monitoring Initiative. The use of trade names does not imply endorsement by the U.S. Government.

\section{References}

Berger, L., Spear, R., Daszak, P., Green, D.E., Cunningham, A.A., GogGin, C.L. et al. (1998) Chytridiomycosis causes amphibian mortality associated with population declines in the rain forests of Australia and Central America. Proceedings of the National Academy of Sciences of the United States of America, 95, 9031-9036.

Bradford, D.F., Graber, D.M. \& Tabatabai, F. (1994) Population declines of the native frog, Rana muscosa, in Sequoia and Kings Canyon National Park, California. Southwestern Naturalist, $39,323-327$.

Briggs, C.J., Knapp, R.A. \& Vredenburg, V.T. (2010) Enzootic and epizootic dynamics of the chytrid fungal pathogen of amphibians. Proceedings of the National Academy of Sciences of the United States of America, 107, 9695-9700.

Herp Net (2013) HerpNet. Http://www.herpnet.org [accessed 17 September 2013].

Hyatt, A.D., Boyle, D.G., Olsen, V., Boyle, D.B., Berger, L., Obendorf, D. et al. (2007) Diagnostic assays and sampling 
protocols for the detection of Batrachochytrium dendrobatidis. Diseases of Aquatic Organisms, 73, 175-192.

IUCN (2013) IUCN Red List of Threatened Species v. 2013.1. Http://www.iucnredlist.org [accessed 17 September 2013].

Jennings, M.R. \& Hayes, M.P. (1994) Decline of native ranid frogs in the desert southwest. In Herpetology of the North American Deserts: Proceedings of a Symposium (eds P.R. Brown \& J.W. Wright), pp. 183-211. Southwestern Herpetologists Society, Van Nuys, USA.

Knapp, R.A. \& Matthews, K.R. (2000) Non-native fish introductions and the decline of the mountain yellow-legged frog from within protected areas. Conservation Biology, 14, $428-438$.

LAAKE, J. \& Rexstad, E. (2012) RMark-an alternative to building linear models in MARK. In Program MARK: A Gentle Introduction, 11th edition (eds E. Cooch \& G. White), pp. C1-C115. Http://www.phidot.org/software/mark/docs/book/ [accessed 28 October 2013].

LAAKE, J. with contributions from Rakhimberdiev, E., Collier, B., Rotella, J. \& Paul, A. (2012) RMark: R Code for MARK Analysis. R package version 2.1.3. Http://CRAN.R-project.org/ package $=$ RMark [accessed 28 October 2013].

Leviton, A.E., Gibbs, R.H.J., Heal, E. \& Dawson, C.E. (1985) Standards in herpetology and ichthyology: Part I. Standard symbolic codes for institutional resource collections in herpetology and ichthyology. Copeia, 1985, 802-832.

Lips, K.R., Brem, F., Brenes, R., Reeve, J.D., Alford, R.A., VOYLES, J. et al. (2006) Emerging infectious disease and the loss of biodiversity in a Neotropical amphibian community. Proceedings of the National Academy of Sciences of the United States of America, 103, 3165-3170.

LUKacs, P. (2012) Closed population capture-recapture models. In Program MARK: A Gentle Introduction, 11th edition (eds E. Cooch \& G. White), Chapter 14. Http://www.phidot.org/software/mark/docs/ book/ [accessed 28 October 2013].

Macey, J.R., Strasburg, J.L., Brisson, J.A., Vredenburg, V.T., Jennings, M. \& Larson, A. (2001) Molecular phylogenetics of western North American frogs of the Rana boylii species group. Molecular Phylogenetics and Evolution, 19, 131-143.

MacKenzie, D.I., Nichols, J.D., Lachman, G.B., Droege, S. Royle, J.A. \& LANGtimm, C.A. (2002) Estimating site occupancy when detection probabilities are less than one. Ecology, 83, 2248-2255.

Muths, E., Corn, P.S., Pessier, A.P. \& Green, D.E. (2003) Evidence for disease-related amphibian decline in Colorado. Biological Conservation, 110, 357-365.

Pimm, S.L., Jones, H.L. \& Diamond, J.M. (1988) On the risk of extinction. American Naturalist, 132, 757-785.

R Development Core Team. (2012) R: A Language and Environment for Statistical Computing. R Foundation for Statistical Computing, Vienna, Austria.

Schoenherr, A.A. (1976) The Herpetofauna of the San Gabriel Mountains, Los Angeles County, California. Including Distribution and Biogeography, pp. 1-95. Special Publication of the Southwestern Herpetological Society, Los Angeles, USA.

Schoville, S.D., Tunstall, T.S., Vredenburg, V.T., Backlin, A.R., Gallegos, E.A., Wood, D.A. \& Fisher, R.N. (2011) Conservation genetics of evolutionary lineages of the endangered mountain yellow-legged frog, Rana muscosa (Amphibia: Ranidae), in southern California. Biological Conservation, 144, 2031-2040.

Stebinss, R.C. (2003) A Field Guide to Western Reptiles and Amphibians, 3rd ed. Houghton Mifflin Company, Boston, USA.

Stebbins, R.C. \& Cohen, N.W. (1997) A Natural History of Amphibians. Princeton University Press, Princeton, USA.

U.S. Fish And Wildlife Service (2002) Endangered and threatened wildlife and plants; determination of endangered status for the southern California distinct vertebrate population segment of the mountain yellow-legged frog (Rana muscosa). Federal Register, $67,44382-44392$.

Vredenburg, V.T., Fellers, G. \& Davidson, C. (2005) The mountain yellow-legged frog Rana muscosa Camp. 1917. In Amphibian Decline: The Conservation Status of United States Species (ed. M. Lannoo), pp. 563-566. University of California Press, Berkeley, USA.

Vredenburg, V.T., Bingham, R., Knapp, R., Morgan, J.A.T., Moritz, C. \& WAKe, D. (2007) Concordant molecular and phenotypic data delineate new taxonomy and conservation priorities for the endangered mountain yellow-legged frog. Journal of Zoology, 271, 361-374.

Vredenburg, V.T., Knapp, R.A., Tunstall, T.S. \& Briggs, C.J. (2010) Dynamics of an emerging disease drive large-scale amphibian population extinctions. Proceedings of the National Academy of Sciences of the United States of America, 107, 9689-9694.

White, G.C. \& Burnham, K.P. (1999) Program MARK: survival estimation from populations of marked animals. Bird Study 46 (Supplement), 120-138.

Wright, A.H. \& Wright, A.A. (1949) Handbook of Frogs and Toads of the United States and Canada, 3rd edition. Comstock Publishing, Ithaca, USA.

ZweifeL, R.G. (1955) Ecology, distribution, and systematics of frogs of the Rana boylii group. University of California Publications in Zoology, 54, 207-291.

\section{Biographical sketches}

This U.S. Geological SuRvey team has a common interest in stabilizing extant Rana muscosa populations and restoring them across the mountains of southern California. ADAM BACKLIN, CyNTHIA HitchCOCK and Elizabeth Gallegos focus their research on the natural history, historical distribution and conservation options to achieve these goals. JULIE YEE has been a statistician with USGS since 1997. ROBERT Fisher's research involves natural history, biogeography, invasive species, and distribution to determine baseline conditions and current and future effects to better inform conservation management. 